\title{
THE STUDY OF OPTICAL PROPERTIES OF $\mathrm{Mg}_{\mathrm{x}} \mathrm{N}_{1-\mathrm{x}} \mathrm{Fe}_{2} \mathrm{O}_{4} / \mathrm{SiO}_{2}$ NANOCOMPOSITE AGAINST THE METHYLENE BLUE PHOTODEGRADATION
}

\author{
Rachmad Almi Putra ${ }^{1 *}$, Fajriani ${ }^{1}$, Wan Alamsyah ${ }^{2}$, Puji Wahyuningsih $^{3}$, Hendri Sahputra ${ }^{4}$ \\ ${ }^{1}$ Physics Study Program, the Faculty of Engineering, Universitas Samudra, Jl. Iskandar Muda \\ No. 4-6, Langsa 24415, Indonesia \\ ${ }^{2}$ Department of Civil Engineering, the Faculty of Engineering, Universitas Samudra, Jl. \\ Merandeh, Langsa 24415, Indonesia \\ ${ }^{3}$ Chemistry Study Program, the Faculty of Engineering, Universitas Samudra, Jl. Iskandar Muda \\ No. 4-6, Langsa 24415, Indonesia \\ ${ }^{4}$ Physics Education Study Program, the Faculty of Education and Teacher Training, \\ UniversitasSamudra, Jl. Iskandar Muda No. 4-6, Langsa 24415, Indonesia \\ Received: $6^{\text {th }}$ March 2019; Revised: $17^{\text {th }}$ April 2019; Accepted: $29^{\text {th }}$ April 2019
}

\begin{abstract}
The synthesis of $\mathrm{Mg}_{\mathrm{x}} \mathrm{N}_{1-\mathrm{x}} \mathrm{Fe}_{2} \mathrm{O}_{4} / \mathrm{SiO}_{2}$ composite nanoparticles, where $\mathrm{x}=0,0.25,0.5$, $0.75,1.0$ through coprecipitation method and low temperatures had been successfully carried out. The result of X-ray Diffractometer (XRD) informed that the sample had crystalline forms and different crystallite sizes as the $\mathrm{Mg}$ concentration in the sample is increased. The sizes of crystallite produced were between 12.12 to $24.47 \mathrm{~nm}$. In addition, theoretically and experimentally there were differences grid parameters with the energy bandgap of the nanocomposite sample ranged from 2.51 to 2.66 electron volt $(\mathrm{eV})$. Therefore, the $\mathrm{Mg}_{\mathrm{x}} \mathrm{N}_{1-\mathrm{x}} \mathrm{Fe}_{2} \mathrm{O}_{4} / \mathrm{SiO}_{2}$ composite nanoparticles could be referred to the nano-photocatalyst or nano-adsorbent for organic pollutant due to its potential to degrade Methylene Blue waste.
\end{abstract}

Keywords: $\mathrm{Mg}_{\mathrm{x}} \mathrm{N}_{1-\mathrm{x}} \mathrm{Fe}_{2} \mathrm{O}_{4}$, Composite; Photodegradation; Methylene; Blue.

\section{Introduction}

Photocatalysis a substance that can accelerate the reaction by utilizing photons as its energy source trigger. ${ }^{1}$ Semiconductor materials play a role as a photocatalyst material. If the materials are exposed to sunlight, electrons and holes will be produced, of which act as oxidation and reduction agents in the photocatalyst reaction.

In recent years, research on photocatalytic materials has been focused on semiconductorbased heterogeneous photocatalyst. The materials have photocatalytic and magnetic properties that are good in their use. Among the many heterogeneous photocatalytic materials, ferrite nanoparticles get a number of attention from researchers. ${ }^{2}$ They have a narrow optical slit and visible, decent and heat-resistant light. Ferrite nanoparticles also have beneficial magnetic properties.

Ferrite nanoparticles have been widely studied and applied to various fields of technology, such as data storage technology, medical diagnostics, cancer detectors, microwave absorbers, and transformer cores. The unique properties possessed by spinel ferrite nanoparticles are influenced by their distinctive crystal structure, namely the spinel structure. ${ }^{3}$ The spinel crystal structure is

\footnotetext{
*Corresponding author.

E-Mail: rachmad.almi@unsam.ac.id
} 
related to the configuration and distribution of ions in the crystal lattice of nanoparticle, which are affected by the chemical formula. ${ }^{4}$

Basically, the spinel crystal structure of nanoparticles is defined by the chemical formula $\mathrm{MFe}_{2} \mathrm{O}_{4}$, where $M$ is the divalent cations of $3 \mathrm{~d}$ transitional elements $\left(\mathrm{M}^{2+}=\mathrm{Ni}^{2+}\right.$, $\left.\mathrm{Mg}^{2+}, \mathrm{Zn}^{2+}, \mathrm{Co}^{2+}, \mathrm{Mn}^{2+}\right){ }^{5}$ This crystal structure has a unit cell consisting of 32 oxygen atoms in a cubic close packing (CCP) and cations are distributed in 8 tetrahedral sub-lattice spaces and 16 octahedral sublattice spaces. The distribution of divalent and trivalent cations $\left(\mathrm{M}^{3+}\right)$ in those sub-spaces greatly influences the magnetic and optical properties of nanoparticles.

Several examples of nanoparticles and their crystal structure, which were frequently studied, are nickel ferrite $\left(\mathrm{NiFe}_{2} \mathrm{O}_{4}\right)$ and magnesium ferrite $\left(\mathrm{MgFe}_{2} \mathrm{O}_{4}\right)$. The latter has a high saturation of magnetization, Curie temperature and electrical resistivity. $\mathrm{MgFe}_{2} \mathrm{O}_{4}$ is also an n-type soft magnetic semiconductor material. This material has an inverted spinel crystal structure. ${ }^{6}$ The nanoparticles of $\mathrm{NiFe}_{2} \mathrm{O}_{4}$, on the other hand, are soft magnetic materials that have certain characteristics such as high magnetic saturation, low coercivity, high magnetic permeability, low anisotropy, high Curie temperature, and low magnetic resistance. ${ }^{7,9}$

Based on the cation distribution and chemical composition, $\mathrm{Mg}_{1-\mathrm{x}} \mathrm{Ni}_{\mathrm{x}} \mathrm{Fe}_{2} \mathrm{O}_{4}$ can be synthesized by combining $\mathrm{NiFe}_{2} \mathrm{O}_{4}$ and $\mathrm{MgFe}_{2} \mathrm{O}_{4}$ nanoparticles. ${ }^{10}$ The concentration of $\mathrm{Mg}^{2+}$ and $\mathrm{Ni}^{2+}$ cations in nanoparticles have an effect on the cation distribution which determines the typical properties of nanoparticles. Increasing the concentration of $\mathrm{Mg}^{2+}$ in nanoparticles also has an impact on the increase of crystal lattice parameters. ${ }^{9}$

The results of research on the crystal structure and optical properties of $\mathrm{Mg}_{\mathrm{x}} \mathrm{N}_{1}$. ${ }_{x} \mathrm{Fe}_{2} \mathrm{O}_{4} / \mathrm{SiO}_{2}$ nanoparticle allowed it to be studied further. This had attracted researcher to due exploration related to various information about the physical optical properties and photodegradation of $\mathrm{Mg}_{\mathrm{x}} \mathrm{N}_{1}$ ${ }_{x} \mathrm{Fe}_{2} \mathrm{O}_{4} / \mathrm{SiO}_{2}$ nanoparticles such as parameters of synthesis and chemical composition. The chemical compositions of nanoparticle play an important role in determining their magnetic properties and crystal structure. Hence, the synthesis of $\mathrm{Mg}_{\mathrm{x}} \mathrm{N}_{1-\mathrm{x}} \mathrm{Fe}_{2} \mathrm{O}_{4} / \mathrm{SiO}_{2}$ nanoparticle can have unique properties in two compounds, $\mathrm{NiFe} 2 \mathrm{O} 4$ and $\mathrm{MgFe} 2 \mathrm{O} 4$. In this case, further research on the effect of magnesium and the concentrations of nickel in the $\mathrm{Mg}_{\mathrm{x}} \mathrm{N}_{1-\mathrm{x}} \mathrm{Fe}_{2} \mathrm{O}_{4} / \mathrm{SiO}_{2}$ nanoparticle synthesized by the coprecipitation method is required. The optical properties of $\mathrm{Mg}_{\mathrm{x}} \mathrm{N}_{1}$ ${ }_{x} \mathrm{Fe}_{2} \mathrm{O}_{4} / \mathrm{SiO}_{2}$ nanoparticle determined using the value optical properties of $\mathrm{Mg}^{2+}$ and $\mathrm{Ni}^{2+}$ concentrations.

The coprecipitation method used to synthesis process because of this method is simple and relatively fast (non-time consuming) and carried out at low temperatures $\left(90^{\circ} \mathrm{C}\right)$ but the synthesis result of the nanoparticles tends to have similar sizes compared to the synthesis results using other methods. In addition, the coprecipitation method has an efficient energy consumption since it does not require further processing in the form of calcination or sintering as was conducted in the previous studies.

\section{Methods}

\section{The Synthesis of $\mathrm{Mg}_{\mathrm{x}} \mathrm{N}_{1-\mathrm{x}} \mathrm{Fe}_{2} \mathrm{O}_{4}$ Nanoparticle}

The nanoparticle of $\mathrm{MgxN} 1-\mathrm{XFe} 2 \mathrm{O} 4 / \mathrm{SiO} 2$ having $x=0,0.25,0.5,0.75,1.0$ was prepared by the coprecipitation method. The chemical used in the research were $\mathrm{MgCl}_{2} 6 \mathrm{H}_{2} \mathrm{O}$, $\mathrm{NiCl}_{2} 6 \mathrm{H}_{2} \mathrm{O}, \mathrm{FeCl}_{3} 6 \mathrm{H}_{2} \mathrm{O}, \mathrm{HCl}$, and $\mathrm{NaOH}$ in pro analyst grade which was purchased from E. Merck through the chemical equation as follows:

$$
\begin{gathered}
2 \mathrm{FeCl}_{3}+\mathrm{xMgCl}_{2}+(1- \\
\mathrm{x}) \mathrm{NiCl}_{2}+18 \mathrm{NaOH}+2 \mathrm{H}_{2} \mathrm{O}+2 \mathrm{HCl} \\
\downarrow \\
2 \mathrm{Mg}_{\mathrm{x}} \mathrm{Ni}_{(1-\mathrm{x})} \mathrm{Fe}_{2} \mathrm{O}_{4}+18 \mathrm{NaCl}+12 \mathrm{H}_{2} \mathrm{O}
\end{gathered}
$$

The solution of $\mathrm{FeCl}_{3}, \mathrm{MgCl}_{2}$, and $\mathrm{NiCl}_{2}$ were prepared by dissolved $\mathrm{FeCl}_{3}, \mathrm{MgCl}_{2}$, and $\mathrm{NiCl}_{2}$ and stirred with rate $500 \mathrm{rpm}$ for 2 minutes at room temperature. After that, 3.37 $\mathrm{mL} \mathrm{HCl} 37 \%$ dissolved in $50 \mathrm{~mL}$ solvent and stirred at room temperature for 5 minutes. The solution $\mathrm{Mg}_{\mathrm{x}} \mathrm{N}_{1-\mathrm{x}} \mathrm{Fe}_{2} \mathrm{O}_{4}$ was obtained by slow 
titration of $\mathrm{NaOH}$ into $\mathrm{Mg}_{\mathrm{x}} \mathrm{N}_{1-\mathrm{x}} \mathrm{Fe}_{2} \mathrm{O}_{4} / \mathrm{SiO}_{2}$ solution under vigorously stirring with a rate of $1000 \mathrm{rpm}$ for 60 minutes and the solution was kept for 30 minutes. Then, it was rinsed with $150 \mathrm{~mL}$ of DI water and deposited one more time over a permanent magnet for 30 minutes. Finally, solids obtained from this step was calcined at $90^{\circ} \mathrm{C}$ for 4 hours and ground become powder.

Table 1. Characteristics of the synthesized precursors.

\begin{tabular}{crrrrr}
\hline \multirow{2}{*}{ Reagen } & \multicolumn{5}{c}{ Qample } \\
\cline { 2 - 6 } & \multicolumn{1}{c}{ SA } & \multicolumn{1}{c}{ SB } & \multicolumn{1}{c}{ SC } & \multicolumn{1}{c}{ SD } & \multicolumn{1}{c}{ SE } \\
\hline $\mathrm{MgCl}_{2} 6 \mathrm{H}_{2} \mathrm{O}$ & 0 & 0.0025 & 0.005 & 0.0075 & 0.01 \\
$\mathrm{NiCl}_{2} 6 \mathrm{H}_{2} \mathrm{O}$ & 0.01 & 0.0075 & 0.005 & 0.0025 & 0 \\
$\mathrm{FeCl}_{2} 6 \mathrm{H}_{2} \mathrm{O}$ & 0.002 & 0.002 & 0.002 & 0.002 & 0.002 \\
\hline
\end{tabular}

Furthermore, the nanoparticles $\mathrm{Mg}_{\mathrm{x}} \mathrm{N}_{1}$. ${ }_{x} \mathrm{Fe}_{2} \mathrm{O}_{4}$ were coated with $\mathrm{SiO}_{2}$ (ratio 1:1). The $\mathrm{SiO}_{2}$ solution was stirred for 5 minutes. Then, $\mathrm{Mg}_{\mathrm{x}} \mathrm{N}_{1-\mathrm{x}} \mathrm{Fe}_{2} \mathrm{O}_{4}$ and the $\mathrm{SiO}_{2}$ solution was mixed and re-sterilized for 5 hours. Finally, the solid dried in the oven at $100{ }^{\circ} \mathrm{C} .{ }^{11}$

\section{Characterization}

The diffractogram of $\mathrm{Mg}_{\mathrm{x}} \mathrm{N}_{1-\mathrm{x}} \mathrm{Fe}_{2} \mathrm{O}_{4} / \mathrm{SiO}_{2}$ particles was performed using XRD Multifex Rigaku with Ni-filtered Copper $\mathrm{K} \alpha$ radiation of wavelength $1.5406 \AA$, operated at $40 \mathrm{kV}$ and $30 \mathrm{~mA}$. The optical properties of materials were analyzed by UV-Vis measurement at a wavelength of $664 \mathrm{~nm}^{2}$

\section{Photodegradation Testing $\mathrm{Mg}_{\mathrm{x}} \mathrm{Ni}_{1}$ - ${ }_{x} \mathrm{Fe}_{2} \mathrm{O}_{4} / \mathrm{SiO}_{2}$}

$\mathrm{Mg}_{0.5} \mathrm{Ni}_{0.5} \mathrm{Fe}_{2} \mathrm{O}_{4} / \mathrm{SiO}_{2}$ samples $(66,7 \% \mathrm{~b} / \mathrm{v})$ dissolved in an erlenmeyer flask and stirred at room temperature with UV radiation for 120 minutes. After that absorbance was measured at wavelength $650 \mathrm{~nm}$ for 30 minutes. $\mathrm{Mg}_{0.5} \mathrm{Ni}_{0.5} \mathrm{Fe}_{2} \mathrm{O}_{4} / \mathrm{SiO}_{2}$ samples were used to degradation methylene blue (20 ppm).

\section{Result and Discussion}

\section{X-ray Diffraction (XRD) Analysis}

Based on the X-ray diffractograms which are shown in Figure 1, $\mathrm{Mg}_{\mathrm{x}} \mathrm{N}_{1-\mathrm{X}} \mathrm{Fe}_{2} \mathrm{O}_{4} / \mathrm{SiO}_{2}$ nanoparticles resulted in peaks 220, 311, 400, 440 , and 622 that could be assumed that the sample was polycrystalline. ${ }^{4}$ The diffraction peaks of $\mathrm{Mg}_{\mathrm{x}} \mathrm{N}_{1-\mathrm{x}} \mathrm{Fe}_{2} \mathrm{O}_{4} / \mathrm{SiO}_{2}$ nanoparticles in accordance with standard data of JCPDS Card No. 88-1935. The diffraction peaks shifted as the increase of concentration $\mathrm{x}(\mathrm{x}=0,0.25,0.5$, $0.75,1.0)$. The shift was occurred due to the composition differences between $\mathrm{Mg}$ and $\mathrm{Ni}$ during synthesis. Besides that, the synthesis process gave effect on the nanoparticles produced. The parameter of lattice and the crystallite sizes could be calculated and estimated using data of diffraction peaks. The rate of the lattice parameter of $\mathrm{a}_{\exp }$ and the crystallite sizes could be calculated by implementing the method of Scherrer's ${ }^{11,12}$ and Origin software. The calculation result of lattice parameters with the variation of magnesium composition $(x=0,0.25,0.5,0.75$, 1.0) is represented in Table 2. 


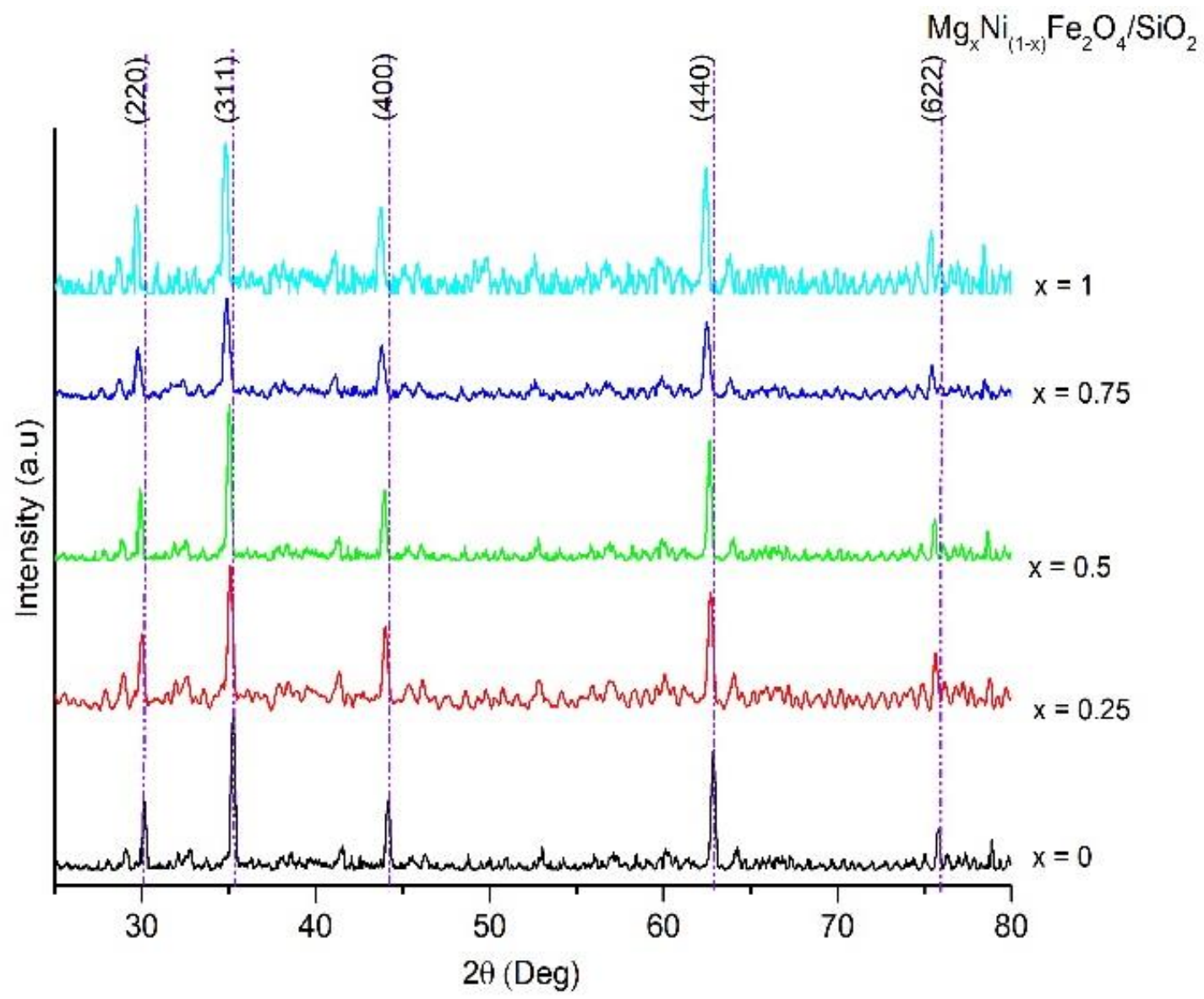

Figure 1. $\mathrm{XRD}$ Pattern for $\mathrm{Mg}_{\mathrm{x}} \mathrm{Ni}_{1-\mathrm{X}} \mathrm{Fe}_{2} \mathrm{O}_{4} / \mathrm{SiO}_{2}$

The data presented in Table 2 showed that the lattice parameters increased as the increase of $\mathrm{Mg}$ concentration within $\mathrm{Mg}_{\mathrm{x}} \mathrm{Ni}_{1}$. ${ }_{x} \mathrm{Fe}_{2} \mathrm{O}_{4} / \mathrm{SiO}_{2}$ nanoparticles. The increase of lattice parameters happened because of the ion exchange. Ions have a larger radius such as $\mathrm{Fe} 3+(0.78 \mathrm{~A})$ and $\mathrm{Mg} 2+(0.72 \mathrm{~A})$ will be replaced with ions smaller radius like $\mathrm{Ni}$ (0.69). $\quad \mathrm{Mg}_{\mathrm{x}} \mathrm{Ni}_{1-\mathrm{x}} \mathrm{Fe}_{2} \mathrm{O}_{4} / \mathrm{SiO}_{2}$ nanoparticles have $\mathrm{Ni}^{2+}$ ions octahedral site $\mathrm{B}$ and $\mathrm{Mg}^{2+}$ ions in tetrahedral site $\mathrm{B}$. Besides that, $\mathrm{Fe}^{3+}$ ions were distributed in both sites. The cation distribution in the nanoparticles could be assumed through the following equation. ${ }^{13}$

$\left[\mathrm{Mg}_{\mathrm{x}}{ }^{2+} \mathrm{Fe}^{3+}{ }_{1-\mathrm{x}}\right]_{\mathrm{A}}\left[\mathrm{Ni}_{1-\mathrm{x}} \mathrm{Fe}^{3+}{ }_{1-\mathrm{x}}\right]_{\mathrm{B}}$

The mean of cation radius on site $\mathrm{A}(\mathrm{rA})$ and site $\mathrm{B}(\mathrm{rB})$ could be calculated by applying the following equation. ${ }^{14}$

$\mathrm{rA}=\left(\mathrm{C}^{\mathrm{A}} \mathrm{Mg}^{2+}\right)\left(\mathrm{r}^{\mathrm{A}} \mathrm{Mg}^{2+}\right)+\left(\mathrm{C}^{\mathrm{A}} \mathrm{Fe}^{3+}\right)\left(\mathrm{r}^{\mathrm{A}} \mathrm{Fe}^{3+}\right)$
$\mathrm{rB}=0.5 *\left(\left(\mathrm{C}^{\mathrm{A}} \mathrm{Ni}^{2+}\right)\left(\mathrm{r}^{\mathrm{A}} \mathrm{Ni}^{2+}\right)+\left(\mathrm{C}^{\mathrm{A}} \mathrm{Fe}^{3+}\right)\left(\mathrm{r}^{\mathrm{A}} \mathrm{Fe}^{3+}\right)\right)$

$\mathrm{C}^{\mathrm{A}}$ and $\mathrm{C}^{\mathrm{B}}$ represent ion concentrations found in tetrahedral and octahedral sites, respectively. Theoretically, the lattice parameters could be calculated by employing the equation as follows. ${ }^{14}$

$a_{t h}=\frac{8}{3 \sqrt{3}}\left[r_{A}+R_{0}+\sqrt{3}\left(r_{B}+R_{0}\right)\right]$

$\mathrm{rA}$ and $\mathrm{rB}$ were the cation radius contained in site $\mathrm{A}$ and $\mathrm{B}$. On the other hand, $\mathrm{R}_{0}$ was the radius of oxygen ion $(0.138 \AA)$. The lattice parameters as shown in Table 2 were retrieved based on the experiment of $\mathrm{a}_{\mathrm{exp}}$, which was theoretically different from the lattice parameters of theoretically $\left(\mathrm{a}_{\mathrm{th}}\right)$. However, both resulted in an increasing pattern as the increase of $\mathrm{Mg}$ concentration (see Figure 2). 


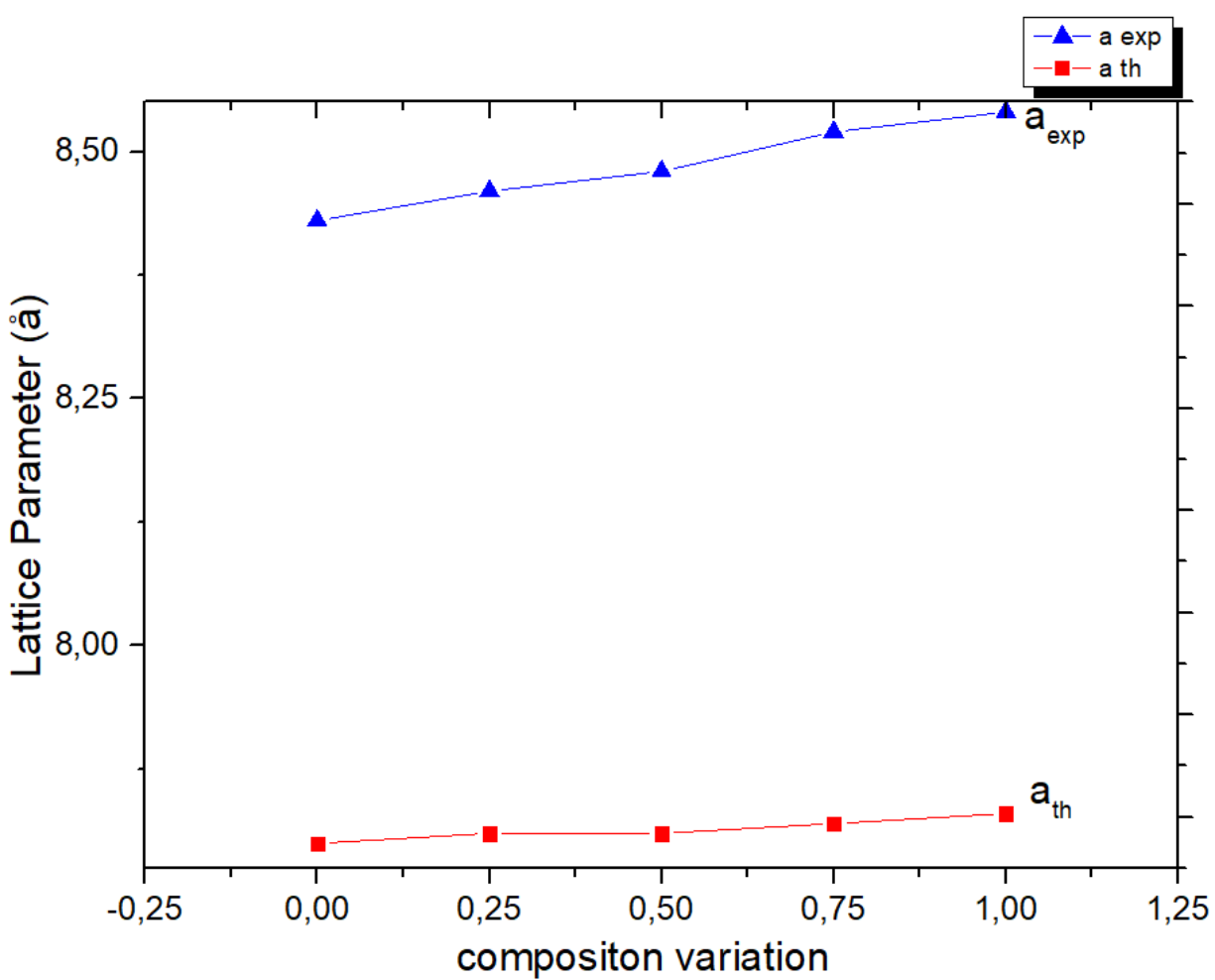

Figure 2. The Comparison Graph between the Lattice Parameters of $a_{\exp }$ and $a_{\text {th }}$ against composition variation

Table 2. Average crystallite size calculated using Scherrer equation Nanocomposite $\mathrm{Mg}_{\mathrm{x}} \mathrm{Ni}_{1-}$ ${ }_{x} \mathrm{Fe}_{2} \mathrm{O}_{4} / \mathrm{SiO}_{2}$

\begin{tabular}{lcclcccccc}
\hline Sample & $\mathbf{X}$ & $\mathbf{2 \theta}\left(\mathbf{(}^{\mathbf{0}}\right)$ & $\mathbf{F W H M}$ & $\mathbf{h k l}$ & $\begin{array}{c}\mathbf{a} \text { exp } \\
(\mathbf{A})\end{array}$ & $\begin{array}{c}\mathbf{a} \text { (th } \\
(\mathbf{A})\end{array}$ & $\mathbf{t}(\mathbf{A})$ & $\mathbf{t}(\mathbf{n m})$ & microstrain \\
\hline SA & 0.00 & 35.28 & 0.010 & 311 & 8.43 & 7.80 & 140.58 & 14.06 & 0.03 \\
SB & 0.25 & 35.12 & 0.009 & 311 & 8.46 & 7.81 & 167.16 & 16.72 & 0.03 \\
SC & 0.50 & 35.04 & 0.012 & 311 & 8.48 & 7.81 & 121.17 & 12.12 & 0.04 \\
SD & 0.75 & 34.90 & 0.006 & 311 & 8.52 & 7.82 & 244.68 & 24.47 & 0.02 \\
SE & 1.00 & 34.78 & 0.010 & 311 & 8.54 & 7.83 & 147.36 & 14.74 & 0.03 \\
\hline
\end{tabular}

The microstrain data in crystal shown in Table 2 assumed that the crystallite formed was not perfect because of the synthesis process was carried out at low temperature. The estimation of crystallite sizes as varied as

The increase of $\mathrm{Mg}$ concentration in the nanoparticles was effected distance between bond length of cation and anion. In site $\mathrm{A}$, the bond length was called $R_{A}$ while it was termed $R_{B}$ in the site $B$. The bond length could be calculated by applying the following equation 5-8. ${ }^{14-15}$

$$
\begin{aligned}
& R_{A}=a \sqrt{3}\left(\delta+\frac{1}{8}\right) \\
& R_{B}=a \sqrt{3 \delta^{2}-\frac{\delta}{2}+\frac{1}{16}}
\end{aligned}
$$

the increase of $\mathrm{Mg}$ concentration. Therefore, the effect of the $\mathrm{Mg}$ concentration towards the crystallite sizes could not be determined correctly.

$$
\begin{aligned}
& \delta=U-0.375 \\
& U=\left[(r A+R o) \frac{1}{\sqrt{3 a}}+\frac{1}{4}\right]
\end{aligned}
$$

where $\delta$ represented the deviation of oxygen atoms. The $R_{A}$ rate increased and the $R_{B}$ decreased as the increase of nickel concentration. Those rates are listed in Table 3. 
Table 3. The Effect of Mg Concentration $(x)$ towards the Rates of $\mathrm{R}_{\mathrm{A}}$ and $\mathrm{R}_{\mathrm{B}}$

\begin{tabular}{ccccc}
$\mathbf{X}$ & $\mathbf{U}$ & $\boldsymbol{\delta}$ & $\mathbf{R}_{\mathbf{A}}$ & $\mathbf{R}_{\mathbf{B}}$ \\
\hline 0.00 & 0.68 & 0.30 & 6.26 & 3.64 \\
0.25 & 0.67 & 0.30 & 6.20 & 3.59 \\
0.50 & 0.67 & 0.29 & 6.14 & 3.53 \\
0.75 & 0.66 & 0.29 & 6.09 & 3.48 \\
1.00 & 0.66 & 0.28 & 6.03 & 3.42 \\
\hline
\end{tabular}

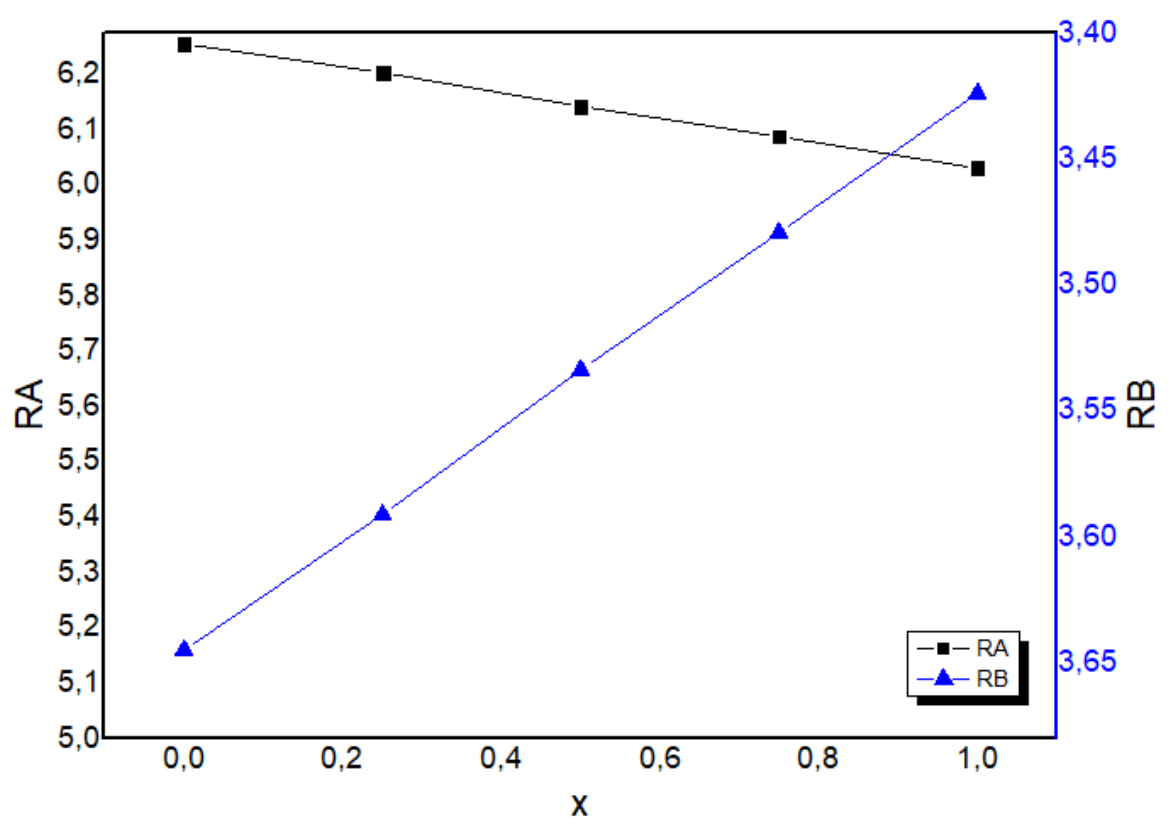

Figure 3. The Graph of the $\mathrm{Mg}$ Concentration $(x)$ Effect on $\mathrm{R}_{\mathrm{A}}$ and $\mathrm{R}_{\mathrm{B}}$

The increase of $\mathrm{Mg}^{2+}$ caused expansion of the tetrahedral site (A) and resulted in shrinkage in the octahedral site (B). The effect of nickel concentration on $\mathrm{RA}$ and $\mathrm{RB}$ is represented in Figure 3.

The trigonal deviation of the oxygen atom coordinate which found in the octahedral site $\mathrm{B}$ was referred to as the urate. The shrinkage of $\mathrm{u}$ rate indicated the occurrence of distortion in the tetrahedral site (A) as the increase of magnesium concentration.

\section{The Optical Properties}

The UV spectrum of $\mathrm{Mg}_{\mathrm{x}} \mathrm{N}_{1-\mathrm{X}} \mathrm{Fe}_{2} \mathrm{O}_{4} / \mathrm{SiO}_{2}$ nanoparticles is demonstrated in Figure 4. The energy has required to excite the electrons from the valence band to the conduction band was called as energy bandgap. The energy bandgap of the nanoparticles was determined by implementing the Kubelka-Munk method. ${ }^{16}$
Furthermore, the energy bandgap of the $\mathrm{Mg}_{\mathrm{x}} \mathrm{N}_{1-\mathrm{x}} \mathrm{Fe}_{2} \mathrm{O}_{4} / \mathrm{SiO}_{2}$ nanoparticles the variations in the composition of $x(x=0,0.25$, $0.5,0.75,1.0$ ) was $2.66 \mathrm{eV}$ to 2.51 (see Figure 5). It had a tendency to be decreased as the increase of the $\mathrm{Mg}$ in the $\mathrm{Mg}_{\mathrm{x}} \mathrm{N}_{1 \text { - }}$ ${ }_{x} \mathrm{Fe}_{2} \mathrm{O}_{4} / \mathrm{SiO}_{2}$ nanoparticles.

Figure 4 showed that the energy bandgap obtained in the nanocomposite of $\mathrm{NiFe}_{2} \mathrm{O}_{4} / \mathrm{SiO}_{2}$ was $2.66 \mathrm{eV}$. This value was different from previous reports. ${ }^{17-18}$ While the energy band gap of $\mathrm{MgFe}_{2} \mathrm{O}_{4} / \mathrm{SiO}_{2}$ nanocomposite was $2.51 \mathrm{eV}$, it similar to the research conducted by A. I. Ahmed et al. ${ }^{19}$ which ranged from $2.40 \mathrm{eV}$ to $2.74 \mathrm{eV}$, but it smaller than the study by R. A. Putra et al. ${ }^{4}$ and A. I. Ahmed et al. ${ }^{19}$ These were caused by microstrain and the crystallite lattices defections due to the synthesis process. Consequently, it could affect the amount of energy band gap as an effect of the quantum confinement. However, if the concentration 
variation between $\mathrm{Ni}$ and $\mathrm{Mg}$ in the $\mathrm{Mg}_{0.5} \mathrm{Ni}_{0.5} \mathrm{Fe}_{2} \mathrm{O}_{4} / \mathrm{SiO}_{2}$ nanocomposite was balanced, the energy bandgap obtained was $2.58 \mathrm{eV}$. Because, $\mathrm{MgFe}_{2} \mathrm{O}_{4} / \mathrm{SiO}_{2}$ has difference ability compared by $\mathrm{NiFe}_{2} \mathrm{O}_{4} / \mathrm{SiO}_{2}{ }^{4,20-22}$ Combination of the two types of ferrite has produced difference photodegradation activity from each composite. It is the reason for the selection of $\mathrm{Mg}_{0.5} \mathrm{Ni}_{0.5} \mathrm{Fe}_{2} \mathrm{O}_{4} / \mathrm{SiO}_{2}$ nanocomposite for photodegradation activity investigation of methylene blue.

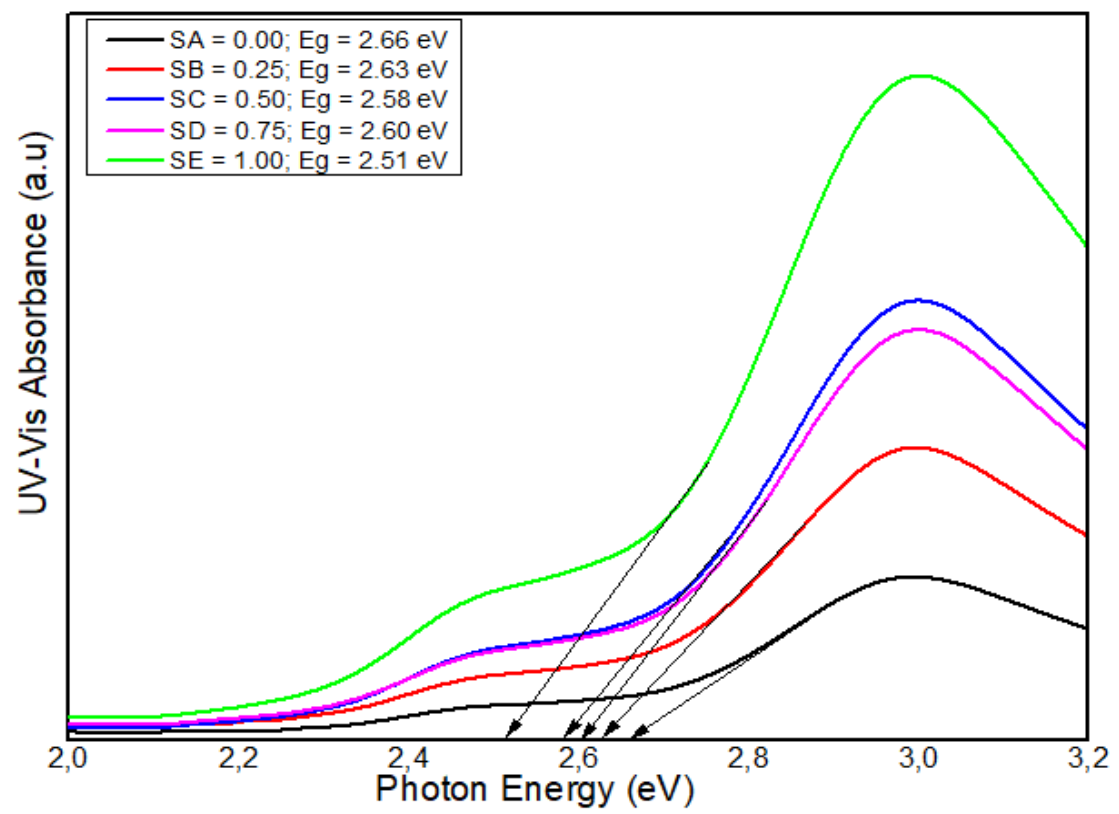

Figure 4. Toch's Plot

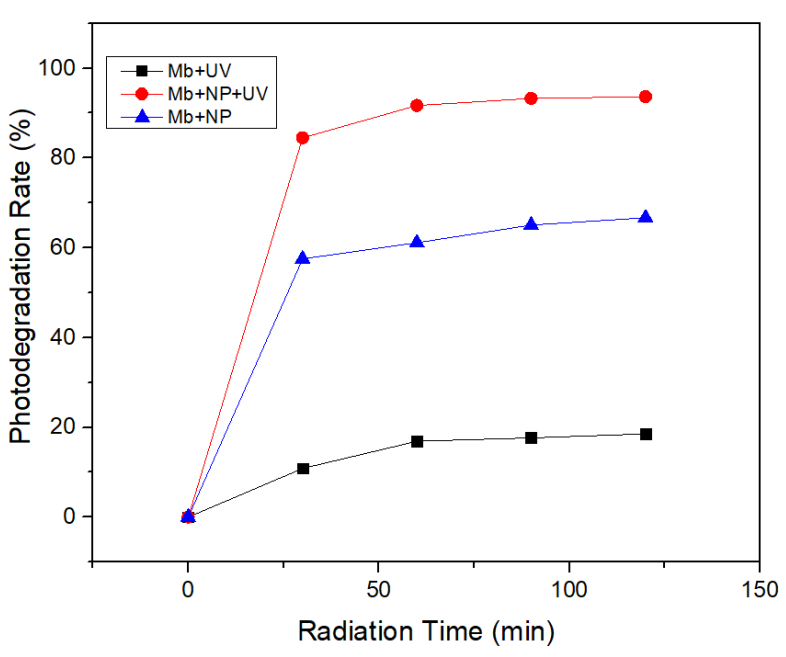

(a)

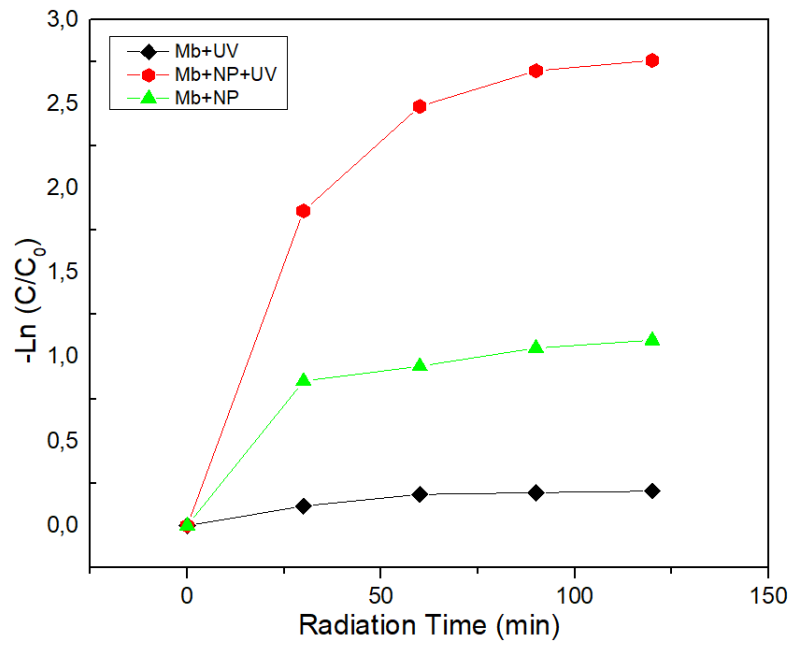

(b)

Figure 5. (a) Photodegradation Rate of $\mathrm{Mg}_{0.5} \mathrm{Ni}_{0.5} \mathrm{Fe}_{2} \mathrm{O}_{4} / \mathrm{SiO}_{2}$ Nanocomposite, (b) Photodegradation Kinetics of the Sample

\section{The Photodegradation}

The photodegradation activity of $\mathrm{Mg}_{0.5} \mathrm{Ni}_{0.5} \mathrm{Fe}_{2} \mathrm{O}_{4} / \mathrm{SiO}_{2}$ nanocomposite was carried out using methylene blue with varying radiation times $0,30,60,90$, and 120 minutes respectively. In the radiation process, there is an interaction between the photocatalyst and light so the electrons must interact with methylene blue. Therefore, the longer the duration the more effective the interaction between light and electrons in forming a number of electrons on the surface. The electrons were formed because of electron 
excitation in the valence band leading to the conduction band. As a result, it produced a strong oxidizing hole to form $\mathrm{Mg}^{2+}$ radicals.

The percentage of photodegradation increased from 0 to 120 minutes then at 90 120 minutes it decreased. This is due to the attachment of $\mathrm{Mg}_{0.5} \mathrm{Ni}_{0.5} \mathrm{Fe}_{2} \mathrm{O}_{4}$ nanocomposite photoreduction yielded the interactions between the sample and UV radiation weakly and caused photodegradation reaction proceeded slowly. Figure 5 showed that the amount of the electrons produced was reduced which caused the photodegradation reaction ran slowly. $\mathrm{Mg}_{0.5} \mathrm{Ni}_{0.5} \mathrm{Fe}_{2} \mathrm{O}_{4}$ nanocomposite can be potential as nano photocatalyst or nano-absorbent for organic pollutants because it can degrade organic pollutants with or without UV radiation.

\section{Conclusions}

By employing the coprecipitation method, the composite nanoparticles had been synthesized with the variations of $\mathrm{Mg}(x=0.0$, $0.25,0.5,0.75,1.0)$ in $\mathrm{Mg}_{\mathrm{x}} \mathrm{N}_{1-\mathrm{x}} \mathrm{Fe}_{2} \mathrm{O}_{4} / \mathrm{SiO}_{2}$. The characterization result of XRD confirmed that the sample was crystalized and had energy bandgap around 2.66 to $2.51 \mathrm{eV}$. In addition, the nanoparticles showed the activity of photodegradation against Methylene Blue. The nanoparticle composite could be good nano-photocatalyst and nano-absorbent agents for the pollutant.

\section{Acknowledgements}

The researchers would like to thank Kementrian Riset, Teknologi, dan Pendidikan Tinggi (the Ministry of Research, Technology and Higher Education), which offered research funding through a Research Program Penelitian Dosen Pemula with the contract issue 209/UN54.6/LT/2019.

\section{References}

1. A. Risda Tussa'adah. Sintesis Material Fotokatalis $\mathrm{TiO} 2$ Untuk Penjernihan Limbah Tekstil. Fis. Unand. 2015;4(1):p. 91-96,

2. Indrayana. UV Light-Driven Photodegradation of Methylene Blue by
Using UV Light-Driven

Photodegradation of Methylene Blue. 2018:pp. 0-5

3. D. S. Mathew and R. S. Juang. An overview of the structure and magnetism of spinel ferrite nanoparticles and their synthesis in microemulsions. Chem. Eng. J. 2007;1299(1-3):pp. 51-65.

4. R. A. Putra, W. Alamsyah, and I. P. T. Indrayana. Characterization Of Microstructural And Optical Properties of $\begin{array}{llllll}\mathrm{MgFe} & 2 & \mathrm{O} & 4 & \text { Nanoparticles For }\end{array}$ Photocatalyst of Mercury ( $\mathrm{Hg}$ ). 2018;11(1):pp. 1-5

5. A. Yan et al.,.Solvothermal synthesis and characterization of size-controlled $\mathrm{Fe} 3 \mathrm{O} 4$ nanoparticles. J. Alloys Compd.,.2008;458(1-2):pp. 487-491.

6. S. K. Pradhan, S. Sain, and H. Dutta. Microstructure Characterization of Nanocrystalline Magnesium Ferrite Annealed at Elevated Temperatures by Rietveld Method. 2011.

7. M. Srivastava, S. Chaubey, and A. K. Ojha. Investigation on size dependent structural and magnetic behavior of nickel ferrite nanoparticles prepared by sol-gel and hydrothermal methods. Mater. Chem. Phys.,.2009;118(1):pp. 174-180.

8. T. Jahanbin, M. Hashim, K. Amin, and S. Bawa. Influence of sintering temperature on the structural, magnetic and dielectric properties of $\mathrm{Ni} 0.8 \mathrm{Zn} 0.2 \mathrm{Fe} 2 \mathrm{O} 4$ synthesized by co-precipitation route. J. Alloys Compd.,.2010;503(1):pp. 111117.

9. T. F. Marinca, I. Chicinaş, O. Isnard, V. Pop, and F. Popa. Synthesis, structural and magnetic characterization of nanocrystalline nickel ferrite- $\mathrm{NiFe} 2 \mathrm{O} 4$ obtained by reactive milling. J. Alloys Compd.,. 2011;509(30):pp. 7931-7936.

10. V. K. Mittal, S. Bera, R. Nithya, M. P. Srinivasan, S. Velmurugan, and S. V Narasimhan. Solid state synthesis of Mg$\mathrm{Ni}$ ferrite and characterization by XRD and XPS. J. Nucl. Mater., 2004;335:pp. 302-310.

11. T. E. Putri, D. Setiawati, and E. 
Suharyadi. Studi Adsorpsi Logam Fe ( II ), Ni ( II ), dan $\mathrm{Cu}$ ( II ) dalam Limbah Cair Buatan Menggunakan Adsorben Nanopartikel Magnesium Ferrite. 2015 April:pp. 204-207.

12. E. R. Kumar et al.,.SC. Sensors Actuators A. Phys., 2018.

13. I. Sharifi, H. Shokrollahi, M. Mahdi, and R. Safi. Journal of Magnetism and Magnetic Materials Magnetic and structural studies on $\mathrm{CoFe} \quad 2 \quad \mathrm{O} \quad 4$ nanoparticles synthesized by coprecipitation, normal micelles and reverse micelles methods. J. Magn. Magn. Mater.,. 2012;324(10):pp. 18541861.

14. K. A. Mohammed, A. D. Al-rawas, A. M. Gismelseed, A. Sellai, H. M. Widatallah, and A. Yousif, "Author' s personal copy."

15. P. Taylor, A. Sankaramahalingam, J. B. Lawrence, A. Sankaramahalingam, and J. B. Lawrence. Synthesis and Reactivity in Inorganic , Metal-Organic , and NanoMetal Chemistry Structural , Optical , and Magnetic Properties of $\mathrm{MgFe} 2 \mathrm{O} 4$ Synthesized with Addition of Copper Structural , Optical , and Magnetic Properties of $\mathrm{MgFe} 2 \mathrm{O} 4$ Synthesized with. October 2014:pp. 37-41.

16. M. Yakob, H. Umar, P. Wahyuningsih, and R. A. Putra. Characterization of microstructural and optical $\mathrm{CoFe} 2 \mathrm{O} 4$ / $\mathrm{SiO} 2$ ferrite nanocomposite for photodegradation of methylene blue. 2019;6(January):pp. 45-51.
17. M. Parishani, M. Nadafan, Z. Dehghani, R. Malekfar, and G. H. H. Khorrami. Results in Physics Optical and dielectric properties of NiFe $2 \mathrm{O} 4$ nanoparticles under different synthesized temperature. Results Phys., 2017;7:pp. 3619-3623.

18. J. A. Jim and M. J. Mel, "ScienceDirect Optical properties determination of $\mathrm{NiFe}$ 2 O 4 nanoparticles and their photocatalytic evaluation towards hydrogen production. 2017:pp. 2-8.

19. A. I. Ahmed, M. A. Siddig, A. A. Mirghni, M. I. Omer, and A. A. Elbadawi. Structural and Optical Properties of $\mathrm{Mg}$ 1-x $\mathrm{Zn} \quad \mathrm{x} \quad \mathrm{Fe} \quad 2 \quad \mathrm{O} \quad 4$ Nano-Ferrites Synthesized Using Co-Precipitation Method. Sci. Res. Publ., 2015;4(May):pp. 45-52.

20. B. T. Chiad and R. A. Mohammed. Spectroscopy, Optical Properties of $\mathrm{NiFe} 2 \mathrm{O} 4$ Nanoparticles Prepared by CoSputtering Technique in Different Gasses Mixture Ratio. 2017;6:pp. 56-58.

21. D. Lv et al.,.Magnetic NiFe $2 \mathrm{O} 4 / \mathrm{BiOBr}$ composites : One-pot combustion synthesis and enhanced visible-light photocatalytic properties. Sep. Purif. Technol.,. 2016;158:pp. 302-307.

22. Z. Y. Kong, N. X. Wong, S. W. Lum, S. Y. Tan, M. R. Khan, and C. K. Cheng. The application of magnesium ferrite photocatalyst for photo treatment of methylene blue. J. Eng. Sci. Technol.,. 2015;10(4):pp.1-10. 